\title{
(Pro)renin Receptor in Kidney Development and Disease
}

\author{
Renfang Song and Ihor V. Yosypiv \\ Section of Pediatric Nephrology, Department of Pediatrics, Hypertension and Renal Center of Excellence, \\ Tulane University Health Sciences Center, 1430 Tulane Avenue, New Orleans, LA 70112, USA \\ Correspondence should be addressed to Ihor V. Yosypiv, iiosipi@tulane.edu
}

Received 6 February 2011; Revised 20 March 2011; Accepted 20 April 2011

Academic Editor: Franz Schaefer

Copyright ( $) 2011$ R. Song and I. V. Yosypiv. This is an open access article distributed under the Creative Commons Attribution License, which permits unrestricted use, distribution, and reproduction in any medium, provided the original work is properly cited.

\begin{abstract}
The renin-angiotensin system (RAS), a key regulator of the blood pressure and fluid/electrolyte homeostasis, also plays a critical role in kidney development. All the components of the RAS are expressed in the developing metanephros. Moreover, mutations in the genes encoding components of the RAS in mice or humans are associated with a broad spectrum of congenital anomalies of the kidney and urinary tract (CAKUT). These forms of CAKUT include renal papillary hypoplasia, hydronephrosis, duplicated collecting system, renal tubular dysgenesis, renal vascular abnormalities, and aberrant glomerulogenesis. Emerging evidence indicates that (pro)renin receptor (PRR), a novel component of the RAS, is essential for proper kidney development and that aberrant PRR signaling is causally linked to cardiovascular and renal disease. This paper describes the role of the RAS in kidney development and highlights emerging insights into the cellular and molecular mechanisms by which the PRR may regulate this critical morphogenetic process.
\end{abstract}

\section{Introduction}

1.1. Brief Overview of Kidney Development. During embryogenesis, the nephric duct (ND) is formed from the intermediate mesoderm on embryonic (E) day E22 in humans and E8 in mice [1]. The ND extends caudally and induces adjacent intermediate mesoderm to form two transient kidney types, pronephros and mesonephros. The pronephros degenerates in mammals, whereas the mesonephros involutes in females, but gives rise to male reproductive organs [1]. On 5 th week of gestation in humans (E10.5 in mice), the caudal portion of the ND forms an epithelial outgrowth called the ureteric bud (UB). The metanephric kidney arises from two embryonic tissues: the UB and the metanephric mesenchyme (MM) [2,3] (Figures 1(a)-1(d)). UB grows out from the ND, elongates, invades the MM, and then branches repeatedly within the mesenchyme to form the renal collecting system (the ureter, pelvis, calyces, and collecting ducts) [3-5]. Linear arrays of inner (medullary) collecting ducts converge centrally to form the papilla. Distal ureter subsequently translocates from the ND to fuse with the bladder which originates from the urogenital sinus (Figures $1(\mathrm{e})-1(\mathrm{~g})$ ) $[6,7]$. Terminal UB tips induce surrounding MM-derived nephron progenitors to condense and then differentiate into nephrons (from the glomerulus to the distal tubule), thus forming the metanephric kidney (Figures $1(\mathrm{a})-1(\mathrm{~d}))[3,4]$.

1.2. Wnt Signaling in Metanephric Kidney Development. Metanephric kidney development depends on reciprocal interactions of transcription and growth factors expressed in the metanephric mesenchyme, stroma and the UB [3, 8, 9]. The wingless (Wnts) are secreted glycoproteins fundamental for proper kidney development. Wnt ligands bind to extracellular domain of frizzled $(\mathrm{Fz})$ seven trans-membrane domain receptors and, in some cases, the low-density lipoprotein (LRP) 5 and 6 coreceptors to activate distinct intracellular signaling cascades [10-12]. Wnt signaling regulates metanephric kidney development via canonical or noncanonical signaling pathways [13]. Binding of Wnt to its receptor leads to accumulation of $\beta$-catenin in the cytoplasm followed by translocation to the nucleus and interaction with the T-cell factor/lymphoid-enhancing factor (Tcf/Lef) family of transcription factors to regulate gene transcription [14]. In addition, $\beta$-catenin is an important component of cell-cell adherens junctions and interacts with the actin cytoskeleton [15]. The noncanonical Wnt signaling pathway consists of the planar cell polarity/convergent extension (PCP/CE) 


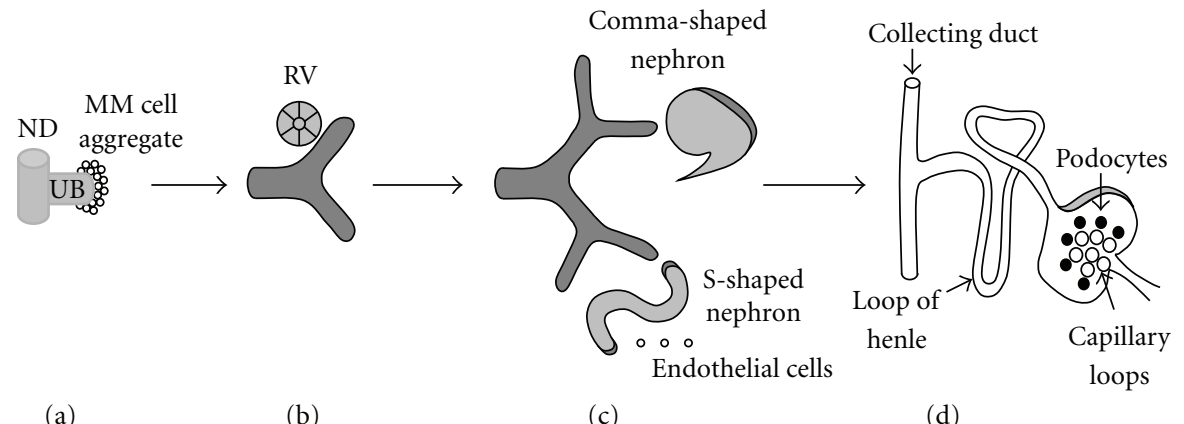

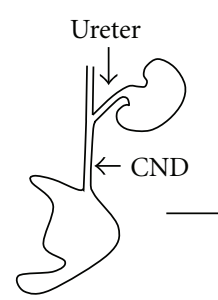

(e)

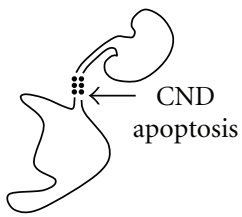

(f)

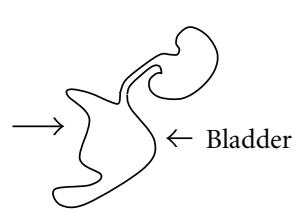

(g)

FIGURE 1: Schematic representation of normal development of the kidney and urinary tract. (a): Invasion of the metanephric mesenchyme (MM) by the ureteric bud (UB) on weeks 5-6 of gestation induces MM cells to aggregate around the UB tip. (a)-(c): UB outgrowth from the nephric duct (ND), its subsequent iterative branching (branching morphogenesis), and continuous condensation of the MM cells around emerging UB tips are induced primarily by reciprocal interactions among glial-derived neurotrophic factor (GDNF), its receptor $c$-Ret, and coreceptor GFR $\alpha 1$. (b): MM cell aggregates undergo mesenchymal-to-epithelial transformation (MET) to form the renal vesicle (RV) on weeks 6-36 of gestation. (c): RV elongates along the proximal-distal axis to form comma-shaped and then S-shaped nephron. Distal ends of S-shaped nephrons fuse with UB-derived collecting ducts, whereas proximal clefts form glomeruli. Endothelial cells migrate into the proximal cleft. UB branching occurs on weeks 6-22 of gestation. Formation of nascent nephrons and their patterning occur on weeks 6-36 of gestation. (d): Patterning of the S-shaped nephron and UB result in formation of mature nephron which contains glomerulat capillary tuft, podocytes, proximal tubule, loop of Henle, distal tubule, and collecting duct. (e). Ureter becomes patent and common ND (CND) fuses with cloaca on weeks 4-5 of gestation. (f): Apoptosis of the CND accounts for the positioning of the ureter (derived from proximal UB) in proximity of the urogenital sinus on weeks 5-6 of gestation. (g): Ureter fuses with the bladder by 6 weeks of gestation (with kind permission from Springer Science + Business Media: [82]). Please see text for details.

pathway and the $\mathrm{Ca}^{2+}$-releasing pathway [13]. PCP controls polarization of cells within the plane of the tissue, whereas CE directs intercalation of cells in an epithelial sheet to form a longer and narrower strip of the tissue [16]. Several Wnts are expressed in the discrete domains of the developing mouse kidney and play a critical role in proper metanephric organogenesis. Wnt6, Wnt7b, Wnt9b, and Wnt11 are expressed in the UB [17-19]. Wnt4 is expressed in the MM and $W n t 2 b$ in the cortical stroma $[17,20]$. Of the Wnts expressed in the metanephros, Wnt2b, Wnt4, Wnt7b, and Wnt9b activate canonical pathway. Wnt signaling is essential for UB branching, nephrogenesis, and medullary patterning. Available data suggest that UB signals to the MM by secreting Wnt9b, a soluble growth factor, which acts via the canonical $\beta$-catenin to induce expression of fibroblast growth factor 8 (FGF8), LIM homeobox 1 (Lhxl) and Wht4 in the MM $[18,21]$. In turn, Wnt4 induces MM cells to undergo mesenchymal-to-epithelial transformation (MET) and differentiate into the nephron epithelia [21]. Genetic inactivation of Wnt $9 b$ or Wnt4 in mice leads to arrest of nephrogenesis at renal vesicle stage, and deficiency of Wnt $9 \mathrm{~b}$ causes severe defects in UB branching [18, 21]. UB-specific inactivation of $\beta$-catenin, the central effector of the canonical
Wht signaling pathway, causes aberrant UB branching and premature differentiation of collecting duct cells and results in renal hypodysplasia $[22,23]$. In addition to directing UB branching and nephrogenesis via the canonical pathway, Wnt9b acts via a noncanonical Wnt pathway to induce PCP in UB-derived collecting ducts. Available evidence suggests that longitudinally oriented cell division (OCD) leads to collecting duct elongation without a change in diameter. In conditions in which collecting ducts dilate to form cysts (e.g., polycystic kidney disease), OCD is randomized, leading to a progressive increase in collecting duct diameter [24]. Mice that lack Wnt9b exhibit dilated collecting ducts, aberrant OCD of the collecting duct cells and develop renal cysts postnatally [25]. Wnt7b-mutant mice do not form renal medulla and papilla [26]. These defects are likely due to aberrant OCD and decreased survival of the medullary collecting duct cells [26].

\section{The Renin-Angiotensin System}

The renin-angiotensin system (RAS) plays a fundamental role in the regulation of arterial blood pressure, 


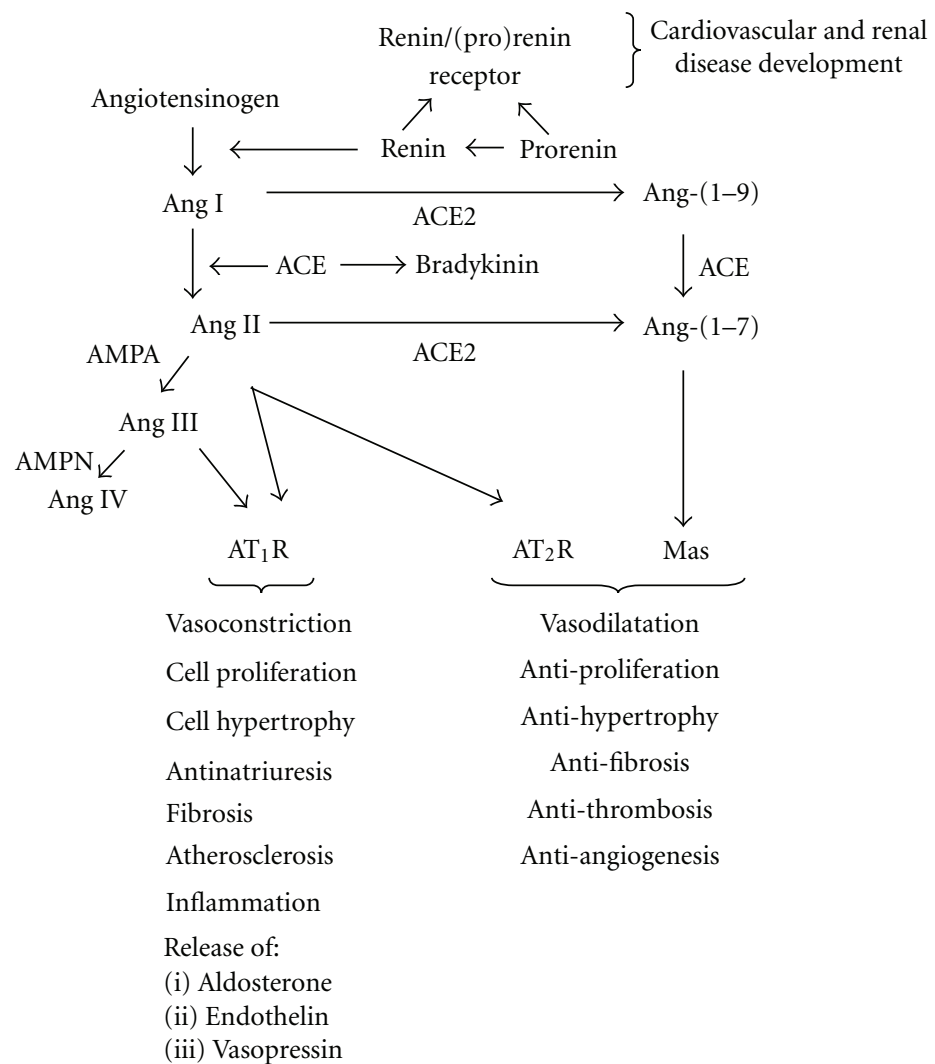

Figure 2: The Renin-Angiotensin System. Ang: angiotensin II. ACE: angiotensin-convertin enzyme, ACE2: angiotensin-converting enzyme 2, AMPA: aminopeptidase A. Please see text for details.

fluid/electrolyte homeostasis, and kidney development [27]. In the RAS, renin cleaves angiotensinogen (AGT) to generate Ang I [Ang-(1-10)] (Figure 2). Ang I is converted by angiotensin-converting enzyme (ACE) to Ang II [Ang-(1-8)], the most powerful effector peptide hormone of the RAS [2830]. Ang II acts via two major $G$ protein-coupled receptors (GPCR): $\mathrm{AT}_{1} \mathrm{R}$ and $\mathrm{AT}_{2} \mathrm{R}$ [29]. Most of hypertensinogenic and sodium-retaining actions of Ang II are attributed to the $\mathrm{AT}_{1} \mathrm{R}$ [31]. In contrast to the $\mathrm{AT}_{1} \mathrm{R}$, the $\mathrm{AT}_{2} \mathrm{R}$ elicits vasodilation, promotes renal sodium excretion, and inhibits proliferation in mesangial cells [32-34]. ACE2 is a homologue of ACE which is abundantly expressed in the kidney and acts to counterbalance ACE activity by promoting Ang II degradation to the vasodilator peptide Ang-(1-7) [35, 36]. Ang-(1-7) acts via the GPCR Mas encoded by Mas protooncogene to oppose Ang II-AT 1 R-mediated effects $[37,38]$. Renin is synthesized in juxtaglomerular cells of the afferent arterioles of the kidney as preprorenin [39]. The human renin gene encoding preprorenin is located on chromosome 1 [40]. Cleavage of a 23 amino acid signal peptide at carboxyl terminus of preprorenin generates prorenin. Prorenin is then converted to active renin by cleavage of 43 -amino acid $\mathrm{N}$-terminal prosegment by proteases [41, 42]. The kidney secretes both renin and prorenin into the peripheral circulation. Plasma levels of prorenin are approximately 10-fold higher than those of renin [43].
In addition to cleaving AGT, renin binds the (pro)renin receptor (PRR) $[44,45]$. The PRR protein is a seven transmembrane domain receptor encoded for by the ATP6AP2 (ATPase-associated protein2)/PRR gene (subsequently referred to as PRR) located on the $\mathrm{X}$ chromosome in humans [44]. The PRR protein exists in three forms: (1) A full-length 35-39 kDa form composed of 3 domains: extracellular, a single transmembrane, and a cytoplasmic, (2) A $28 \mathrm{kDa}$ soluble form found in plasma and urine, and (3) A truncated form containing transmembrane and cytoplasmic domains $[42,45]$. In addition to proteolytic activation via cleavage of the prosegment by proteases, prorenin may be activated by binding to the PRR and undergoing a conformational change that does not require removal of the prosegment [44].

\subsection{Expression of the RAS Components in the Developing} Metanephros. The developing metanephros expresses all the components of the RAS [46-48]. In the fetal mouse kidney, renin mRNA is first detected on E14.5 by in situ hybridization in a few scattered foci of cells [46]. By E15.5, renin is widely expressed in branches of the renal artery, interlobar, and arcuate arteries. In the human kidney, renin mRNA is detected at the vascular pole of the glomerulus and in arteries located next to glomeruli [48]. With fetal maturation, renin expression shifts to its mature localization in the juxtaglomerular cells $[46,48]$. Studies in renin knockin 
reporter mice have demonstrated that renin-producing cells may originate from the mesenchyme at E11-E12 before vessel development has occurred [49]. Ontogeny studies have demonstrated that renal renin synthesis is highly activated during early postnatal development in rodents [47]. Because immunoreactive Ang II levels are higher in the fetal and newborn than adult mouse kidney $[50,51]$, renin is considered to be the rate-limiting factor for Ang II generation during metanephric development. In the adult rat kidney, PRR mRNA and protein are expressed in the collecting duct and the distal nephron [52]. In the CD, the PRR is most abundant at the apical surface of type A intercalated cells where it colocalizes with the vacuolar $\mathrm{H}^{+}$-ATPase [52]. In addition, PRR immunoreactivity is also detected in the podocytes, renal mesangial, vascular smooth muscle, and endothelial cells [53-55]. Even though PRR is expressed in Xenopus pronephros [56], the expression of the PRR gene and PRR protein during metanephric development remains to be determined.

\subsection{Effect of Pharmacological or Genetic Interruption of the} RAS on Kidney Development. Treatment of several animal species or humans with ACE inhibitors or $\mathrm{AT}_{1} \mathrm{R}$ antagonists during gestation or postnatal metanephrogenesis leads to renal tissue dysplasia [57]. A decrease in the number and size of glomeruli, delay in glomerulogenesis, a reduction in the number and length of the renal arteries accompanied by arterial thickening, tubular dilation and a hypoplastic papilla are observed [58]. Nephrotoxic effects of ACE inhibitors and $A T_{1} R$ antagonists in humans include oligohydramnios and anuria $[59,60]$. AGT-, renin-, $A C E-$, or $A T_{1} R$-deficient mice exhibit virtually identical phenotypes characterized by vascular hyperplasia, hydronephrosis, hypoplastic medulla, and papilla [61-66]. Functionally, Renin-, $A C E-$, and $A T_{1} R-$ null animals are polyuric and have a reduced ability to concentrate urine [63-65]. Deletion of the $A T_{2} R$ in mice causes ectopic UB budding from the nephric duct, duplicated collecting systems, and hydronephrosis [67]. Mutations in the genes encoding for $A G T$, renin, $A C E$, or $A T_{1} R$ in humans are associated with renal tubular dysgenesis (RTD) [68, 69]. Kidneys of patients with RTD demonstrate reduced number of proximal tubules, collapsed collecting ducts, enlarged glomeruli, and thickened arteries [69]. Attempts to generate knockout mice with global deletion of the Prr failed [70]. Even though this observation precludes so far determination of the specific role for the PRR in kidney organogenesis, it also indicates that the PRR is essential during development. Targeted inactivation of the Prr gene in mouse cardiomyocytes causes cardiac tissue fibrosis, cardiomyocyte apoptosis, and death within the first several weeks of postnatal life from heart failure [71].

2.3. Signaling Pathways Downstream of the PRR. Even though the cytoplasmic domain of the PRR has no intrinsic kinase activity [48], in vitro studies demonstrate that binding of the PRR by renin or prorenin leads to activation of mitogenactivated protein (MAP) kinases such as Erk1/2 or p38 in renal mesangial and vascular smooth muscle (VSMC) cells and induces phosphorylation of phosphatidylinositol 3-kinase/Akt (PI3K/Akt) in human embryonic kidney (HEK293T) cells [72, 73]. The effect of the PRR on Erk1/2 phosphorylation in human monocytes is independent of Ang II or transactivation of the EGF receptor [74]. In contrast, induction of Erk1/2 and Akt phosphorylation by recombinant rat prorenin in cultured rat VSMCs is independent of Ang II, but dependent on phosphorylation of EGF receptor [75]. Since these changes are blocked by the PRR siRNA, activation of the EGF receptor, Erk1/2, and Akt in VSMC depends on PRR. The importance of the PRR-dependent Erk1/2 activation in brain development is evident from the observations that hypomorphic mutation in the $P R R$ is causally linked to the absence of Erk1/2 phosphorylation and the development of X-linked mental retardation in humans [76].

\subsection{Role of the PRR in Kidney and Cardiovascular Disease.} A direct pathological role of the PRR in renal injury and cardiovascular disease is suggested by the findings of glomerulosclerosis, proteinuria, and elevated blood pressure in rats with ubiquitous transgenic overexpression of the human PRR (Table 1) [91]. Targeted overexpression of the $\mathrm{Prr}$ in the rat vasculature under the control of the mouse smooth muscle myosin heavy chain gene causes mild hypertension after six months of age [77]. Although transgenic overexpression of the prorenin, a major ligand for the PRR, in rats does not cause renal fibrosis, it leads to myocardial hypertrophy, proteinuria, and hypertension [92, 93]. Of interest, since hypertension is controlled by ACE inhibition, it may be due to the increased formation of Ang II [92, 93]. Double-transgenic mice that overexpress human prorenin in the liver and human angiotensinogen in the heart display a selective increase in Ang I content in the heart (but not the plasma) as compared to the single-transgenic mice [94]. These results suggest that circulating prorenin is taken up by tissues where it can contribute to the local synthesis of Ang peptides and tissue damage. Expression of the PRR mRNA and protein is increased in the myocardium and renal tubular, VSMC, and endothelial cells in rats with congestive heart failure due to coronary ligation [54]. Moreover, treatment of spontaneously hypertensive rats (SHRs) with a synthetic peptide that blocks prorenin binding to the PRR reduces renal and cardiac fibrosis $[78,95]$. These data demonstrate that the PRR may contribute to the pathogenesis of heart failure and kidney tissue damage. An important role for the PRR in the pathogenesis of hypertension in humans is supported by the findings that a polymorphism in the $P R R$ gene is associated with a high blood pressure in men (IVS5+169C $>\mathrm{T}$ ) and left ventricular hypertrophy in women $(+1513 \mathrm{~A}>\mathrm{G})[80,81]$.

Although rare cases of human hypertension or CAKUT are due to mutations in single genes, the contribution of the genetic determinants in the vast majority of subjects with high blood pressure or CAKUT remains unknown [82, 96]. If common diseases such as hypertension or nonsyndromic cases of CAKUT are due to multiple gene variants with small effects, large study samples are needed to identify them. 
TABLE 1: Role of (pro)renin receptor (PRR) signaling in kidney development and disease.

\begin{tabular}{|c|c|c|c|c|}
\hline Model & Renal phenotype & Cardiovascular phenotype & Other phenotype & References \\
\hline $\begin{array}{l}\text { Global overexpression of human } \\
P R R \text { in the rat }\end{array}$ & $\begin{array}{l}\text { Glomerulosclerosis } \\
\text { Proteinuria }\end{array}$ & Elevated blood pressure & Unknown & {$[54]$} \\
\hline $\begin{array}{l}\text { Targeted overexpression of human } \\
P R R \text { in rat vasculature }\end{array}$ & Unknown & $\begin{array}{l}\text { Elevated blood pressure and heart } \\
\text { rate }\end{array}$ & Unknown & {$[77]$} \\
\hline SHR rats treated with PRR blocker & $\begin{array}{l}\text { Attenuation of } \\
\text { renal fibrosis }\end{array}$ & Attenuation of cardiac fibrosis & Unknown & {$[78]$} \\
\hline $\begin{array}{l}\text { Mice with targeted deletion of } \mathrm{Pr} \\
\text { in cardiomyocytes }\end{array}$ & Unknown & $\begin{array}{l}\text { Cardiac tissue Fibrosis } \\
\text { Cardiomyocyt opoptosis }\end{array}$ & Unknown & {$[71]$} \\
\hline $\begin{array}{l}\text { Xenopus embryos treated with } \\
\text { anti-PRR morpholino }\end{array}$ & Unknown & Unknown & $\begin{array}{l}\text { Short body axis Impaired CE } \\
\text { Small head } \\
\text { Short tail } \\
\text { Defects in eye pigmentation }\end{array}$ & $\begin{array}{l}{[79]} \\
{[56]}\end{array}$ \\
\hline $\begin{array}{l}\text { Genetic polymorphism of } P R R \text { in } \\
\text { humans }\end{array}$ & Unknown & $\begin{array}{l}\text { Hypertension in men LVH in } \\
\text { women }\end{array}$ & $\begin{array}{l}\text { Unknown } \\
\text { Unknown }\end{array}$ & $\begin{array}{l}{[80]} \\
{[81]}\end{array}$ \\
\hline $\begin{array}{l}\text { Hypomorphic } P R R \text { mutations in } \\
\text { humans }\end{array}$ & Unknown & Unknown & $\begin{array}{l}\text { X-linked mental retardation } \\
\text { Epilepsy }\end{array}$ & {$[76]$} \\
\hline
\end{tabular}

Within the last few years, several genome-wide association studies (GWAS), in which thousands of common genetic variants are analyzed for disease association, identified significant association of a limited number of genes with primary hypertension [97]. Further studies are needed to understand how the implicated genes contribute to such a complex multifactorial disease as primary hypertension. Despite identification of significant association of hypertension with variants of renin, $A C E$ and AGTR1 genes in a study by Zhu et al. [98], the results of RAS gene-association studies are inconsistent [99]. With respect to CAKUT, broad phenotypic spectrum of renal system anomalies and variability in genotype-phenotype correlation demonstrate that pathogenesis of CAKUT is a complex process that depends on interplay of many factors $[82,100]$. It is likely that wellpowered studies utilizing total human exome capture and next-generation sequencing will identify single-gene defects leading to CAKUT.

2.5. Potential Roles for the PRR in Kidney Development. The mechanisms by which the PRR may regulate kidney development may involve changes in the expression of genes or transcription factors that are critical for metanephric organogenesis, physical interaction between the PRR and other receptors or proteins with established roles in renal ontogeny or function, activation of the intracellular signaling pathways, or other mechanisms (Figure 3).

2.5.1. Interaction with the Promyelocytic Zinc Finger Transcription Factor (PLZF). PLZF is a nuclear phosphoprotein which belongs to the POZ/zinc-finger family of transcription factors and is encoded by the Zfp 145 gene. Zfp145-null mice exhibit aberrant expression of Hox genes, defects in limb, and axial skeletal patterning, whereas the kidney phenotype of these mice was not described [101]. Several observations support potential role for PLZF in kidney development. For example, Hox (Hox11) genes are necessary to specify the metanephric kidney identity from the intermediate mesoderm [102]. In patients with acute promyelocytic leukemia, PLZF fuses with the retinoic acid receptor $\alpha(\operatorname{RAR} \alpha)$ and recruits histone deacetylase 1 (HDAC1) to render retinoic acid-target genes unresponsive to retinoic acid, an active form of vitamin A [103]. Both HDAC1 and retinoic acid are essential for embryo development. Genetic inactivation of $H D A C 1$ in mice results in embryonic lethality before E10.5 due to severe proliferation defects [104], whereas RARmutant mice display renal dysplasia [105]. Concerning the RAS, inhibition of HDAC activity induces renin expression in the embryonic kidney $[106,107]$. PRR interacts with the PLZF protein in HEK293 cells in vitro [73]. Moreover, treatment of HEK293 cells with renin causes nuclear translocation of PLZF followed by recruitment of PLZF to the promoters of the PRR and PI3K-p85a genes. This leads to repression of $P R R$ transcription and induction of $P I 3 K$ gene expression [73]. Notably, inhibition of PI3K/Akt blocks UB branching induced by glial-derived neurotrophic factor $(\mathrm{GDNF}) /$ rearranged during transfection (Ret) ligandreceptor pair or by Ang II $[85,86]$.

In addition, PLZF inhibits transcription of $c$-kit in $\mathrm{CD} 4^{+}$hematopoietic progenitor cells (HPC) and in spermatogonia [83, 108]. Functionally, increased $c$-kit expression is necessary to sustain differentiation of these cells. Zfp145null mice exhibit depletion of the proliferative spermatogonial compartment in the testis due to deregulated expression of $c$-kit, which controls a tight balance between spermatogonial self-renewal and differentiation [108]. c-kit is a receptor tyrosine kinase (RTK) for the stem cell factor $(S C F)$, a key regulator of HPC proliferation, survival, and differentiation [83]. Notably, $c$-kit is expressed in the interstitial cell and angioblasts of the developing metanephros [84]. Moreover, antagonism of $c$-kit RTK activity inhibits UB branching and reduces the number of nephrons and renal angioblasts [84]. 
(a)

Fz-PRR

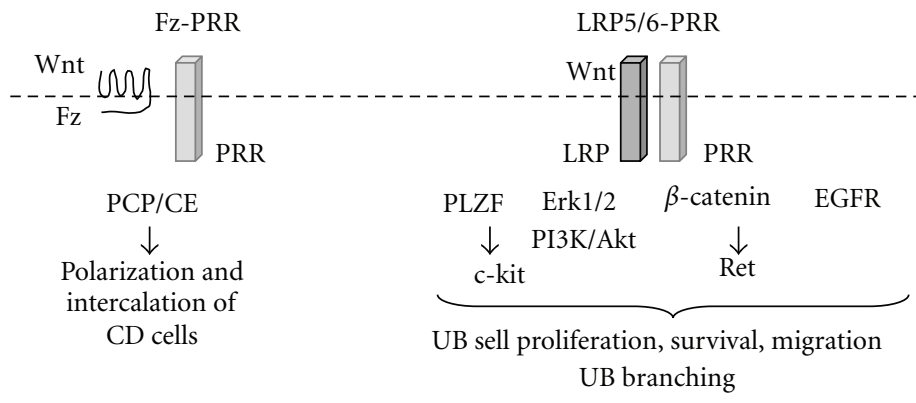

(c)

LRP5/6-PRR-V-ATPase

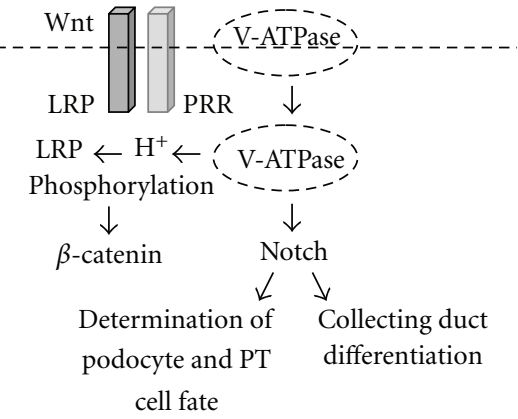

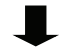

Metanephric organogenesis

FIGURE 3: Proposed mechanisms mediating the effect of the (pro)renin receptor (PRR) in metanephric kidney development. (a): PRR interacts with Wnt receptor frizzled $(\mathrm{Fz})$ to regulate polarization and intercalation of collecting duct (CD) cells via planar cell polarity $(\mathrm{PCP}) /$ convergent extension (CE) Wnt signaling pathway [16, 25, 79]. (b): PRR may regulate UB branching by (1) inhibiting $c$ - kit transcription via promyelocytic zinc finger transcription factor (PLZF) $[73,83,84]$ (2) induction of Erk1/2, PI3K/Akt or epidermal growth factor receptor (EGFR) phosphorylation [52, 72, 73, 75, 85-87], and (3) interaction with LRP5/6 Wnt coreceptor leading to activation of $\beta$-catenin and Ret gene expression [22, 23, 56]. (c): PRR interacts with LRP5/6 and V-ATPase to form a complex at the plasma membrane. Following endocytosis, V-ATPase generates a gradient of $\mathrm{H}^{+}$ions that is essential for LRP5/6 phosphorylation and activation of $\beta$-catenin [56]. V-ATPase stimulates Notch signaling [88]. Notch acts to define the podocyte and proximal tubular cell fates [89] and regulates differentiation of the CD cells [90].

Since PLZF represses $c$-kit expression, loss of PLZF can cause dysregulation of the differentiation of $c$ - $k i t$-positive progenitors of renal interstitial cells and lead to renal hypodysplasia.

\subsubsection{Interactions with the Canonical Wnt/ $\beta$-Catenin Sig-} naling. Another mechanism by which the PRR may control metanephric development is by the regulation of the canonical Wnt/ $\beta$-catenin signaling. Inhibition of the $P R R$ by small inhibitory RNA (siRNA) in HEK293T cells in vitro or by the PRR antisense morpholino in Xenopus embryos in vivo decreases luciferase reporter activity stimulated by canonical Wnt signaling [56]. The PRR binds to Fz8 and LRP6 in HEK293T cells transfected with the PRR expression vector. Activation of LRP6 and $\beta$-catenin signaling depends on extracellular, but not on cytoplasmic or transmembrane, domain of the PRR [56]. Given that canonical Wnt signaling is critical in metanephric organogenesis [22, 23], it is conceivable that direct interaction between the PRR and LRP6 plays an important role in the activation of canonical Wnt signaling via $\beta$-catenin to regulate kidney development. This possibility is supported by the observations that mutations in LRP4, which is known to antagonize LRP6-mediated activation of canonical Wnt signaling, are associated with CAKUT in humans with Cenani-Lenz syndrome (OMIM\# 604270) [109].

2.5.3. Interactions with Noncanonical Wnt/PCP Signaling. In addition to its function in canonical Wnt signaling, PRR modulates Wnt/PCP pathway of the noncanonical Wnt signaling. Treatment of Xenopus embryos with anti-PRR morpholinos causes a short body axis and a broader expression domain of the notochord marker Xnot, a hallmark of impaired convergent extension movements [79]. Aberrant convergent extension (lateral intercalation) of the collecting duct and renal tubular cells may be causally linked to polycystic kidney disease [25]. In addition, Drosophila PRR interacts biochemically with $\mathrm{Fz}$ in HEK293T cells [79]. The Drosophila $\mathrm{Fz}$ receptor is required for PCP. Collectively, PRR mediates both the Wnt/PCP and the Wnt/ $\beta$-catenin signaling pathways. These effects of the PRR are independent of renin $[56,79]$.

2.5.4. Interactions with $V$-ATPase. PRR may regulate kidney development or function via the V-ATPase (Figure 3). VATPase is a multiprotein complex localized in the kidney in intracellular organelles and at the plasma membrane of the intercalated collecting duct cells. Its major function is to pump protons to promote endocytosis [110]. Mutations in the genes encoding the kidney-specific isoforms B1 or A4 of V-ATPase in humans are responsible for inheritable forms of distal renal tubular acidosis, a disease characterized by elevated $\mathrm{H}^{+}$concentrations in the plasma due to the impaired renal excretion of acid $[111,112]$. Critical role for $\mathrm{V}$-ATPase in development is evident from the observation that mutations in the genes encoding subunits $\mathrm{C}$ or $\mathrm{D}$ of V-ATPase in mice result in embryonic lethality $[113,114]$. Mutations in subunits $B 1$ or A3 of V-ATPase in mice cause metabolic acidosis and osteopetrosis, respectively $[115,116]$. Variability in defects observed in these mice indicates that different subunits of V-ATPase have different functions and that subunits A3, A4, and B1 may be important in bone 
remodeling or differentiation of collecting duct cells involved in acid-base homeostasis.

In vitro studies demonstrate that the endogenous PRR binds to the endogenous V-ATPase subunits ATP6V0D1 and ATP6V0C in HEK293T cells [56]. Injection of a dominantnegative V-ATPase subunit E in Xenopus embryos synergizes with anti-PRR morpholino in inhibition of Wnt signaling. Phosphorylation of LRP6, which correlates with LRP6 activation, is inhibited in mouse P19 embryonal carcinoma cells treated with $P R R$ - or V-ATPase siRNA [56]. These findings indicate that the PRR and V-ATPase interact functionally to inhibit Wnt signaling during Xenopus embryonic development in vivo.

Genetic inactivation of the $\mathrm{Prr}$ in cardiomyocytes in mice decreases expression of the $\mathrm{V}(\mathrm{O})$ subunits of $\mathrm{V}$-ATPase, resulting in deacidification of the intracellular vesicles [71]. Thus, the PRR is also essential for vacuolar $\mathrm{H}^{+}$-ATPase assembly in murine cardiomyocytes in vivo. Mutations in VhaAC39, a V-ATPase subunit, in Drosophila are associated with the loss of Notch signaling [88]. Ligand binding to Notch receptor induces proteolytic cleavage and release of the intracellular domain of Notch which enters the cell nucleus to regulate target gene expression. Notch signaling exerts dual function during mouse metanephric development. Notch activity defines the podocyte and proximal tubular cell fates during segmentation of the S-shaped body [89]. In the collecting duct, Notch acts to increase the ratio of principal-to-intercalated cells and regulate urinary concentrating ability [90]. Thus, Notch signaling is required for the differentiation and functional maturation of the principal cells in murine renal collecting duct. Mutations in Notch2 in humans result in Alagille syndrome (OMIM\# 610205) [117]. The renal phenotype in Alagille syndrome is characterized by hypodysplasia. Since PRR is most abundant at the apical surface of type A intercalated cells of the collecting duct, where it colocalizes with the vacuolar $\mathrm{H}^{+}$-ATPase, in the rat [52], the PRR may act in an autocrine fashion to regulate $\mathrm{H}^{+}$transport. During metanephric development, PRR may promote differentiation of $\mathrm{H}^{+}$-secreting intercalated cells in the collecting duct. PRR located on the apical membrane of intercalated cells may be activated in a paracrine fashion by prorenin released by adjacent principal cells [118]. Additional evidence to implicate regulated intracellular acidification in mediating Wnt signaling is provided by the observations that Nhe2, a sodium/proton exchanger in Drosophila and a homologue to human NHE3, interacts genetically with $\mathrm{Fz}$ receptor to regulate Wnt/PCP signaling [119]. Together, these findings suggest that PRR cross-talks with V-ATPase in a renin-independent fashion to regulate both canonical $\mathrm{Wnt} / \beta$-catenin and noncanonical Wnt/PCP signaling.

2.5.5. Regulation of Intracellular Signaling Pathways Critical for Metanephric Kidney Development. Another mechanism by which the PRR may modulate metanephric morphogenesis is via activation of downstream signaling pathways such as PI3K or Erk1/2 [72, 73]. This possibility is supported by an attenuation of Erk1/2 phosphorylation with PRR siRNA in collecting duct/distal tubule lineage Madin-Darby Canine
Kidney (MDCK) cells in vitro [52]. An important role for Erk1/2 and PI3K in kidney development is demonstrated by the findings that inhibition of Erk $1 / 2$ decreases UB branching [120] and that antagonism of PI3K/Akt blocks directional migration of Ret-transfected MDCK cells in response to GDNF in vitro [85]. Critical role of GDNF and Ret in UB morphogenesis is evident from the findings that targeted inactivation of GDNF or Ret in mice results most frequently in bilateral renal agenesis due to a failure of UB outgrowth $[121,122]$. Notably, tyrosine phosphorylation of the EGF receptor and activation of PI3K/Akt and Erk1/2 are also essential for Ang II-induced UB branching [86, 87].

\section{Conclusions and Perspectives}

The PRR is emerging as potential critical player in normal metanephric kidney development. It has become evident that the PRR has an evolutionary conserved role in bridging VATPases with canonical and noncanonical Wnt signaling. Acting via these or other intracellular pathways (e.g., Erk1/2, PI3K), the PRR may regulate segmentation of the proximal nephron and direct functional maturation of UB-derived collecting ducts. Even though significant progress has been made in defining the potential role of the PRR and specific contribution of PRR-dependent signal transduction in metanephric development, further evidence supporting the direct role for the PRR in metanephric organogenesis is needed. What are the perspectives for system-wide approaches to understand the role of the PRR in kidney organogenesis? In this regard, application of new genetic tools, such as conditional/tissue/cell-specific gene knockouts, genetic lineage tracing and fluorescent in vivo reporters of cell signaling, genome-wide analysis of gene regulatory networks (including epigenetic regulation) that control different aspects of kidney development (e.g., microarray, ChIP-Seq) should provide important insights in understanding molecular mechanisms by which the PRR may direct normal and abnormal metanephric kidney development. Defining molecular aberrations leading to CAKUT in animals and humans with mutations in the PRR will uncover biomarkers that can be used for early diagnosis or prevention of renal system anomalies in children. Finally, establishment of shared large biorepositories of patients encompassing a wide spectrum of CAKUT phenotypes for molecular, genetic, and translational studies will define clinically relevant mutations in the $P R R$, its ligands, and interacting genes. The evolution of our understanding of the cellular and molecular mechanisms by which intact PRR controls metanephric kidney development may provide targets for improved diagnosis and prevention of CAKUT in children.

\section{References}

[1] L. Saxen, Organogenesis of the Kidney, Cambridge University Press, Cambridge, UK, 1987.

[2] A. Schedl, "Renal abnormalities and their developmental origin," Nature Reviews Genetics, vol. 8, no. 10, pp. 791-802, 2007. 
[3] F. Costantini and R. Kopan, "Patterning a complex organ: branching morphogenesis and nephron segmentation in kidney development," Developmental Cell, vol. 18, no. 5, pp. 698-712, 2010.

[4] P. Ekblom, "Developmentally regulated conversion of mesenchyme to epithelium," FASEB Journal, vol. 3, no. 10, pp. 2141-2150, 1989.

[5] C. Grobstein, "Inductive epithlio mesenchymal interaction in cultured organ rudiments of the mouse metanephros," Science, vol. 118, no. 2, pp. 52-55, 1953.

[6] E. Batourina, C. Choi, N. Paragas et al., "Distal ureter morphogenesis depends on epithelial cell remodeling mediated by vitamin A and Ret," Nature Genetics, vol. 32, no. 1, pp. 109-115, 2002.

[7] E. Batourina, S. Tsai, S. Lambert et al., "Apoptosis induced by vitamin A signaling is crucial for connecting the ureters to the bladder," Nature Genetics, vol. 37, no. 10, pp. 1082-1089, 2005.

[8] K. J. Reidy and N. D. Rosenblum, "Cell and molecular biology of kidney development," Seminars in Nephrology, vol. 29, no. 4, pp. 321-337, 2009.

[9] G. R. Dressler, "The specification and maintenance of renal cell types by epigenetic factors," Organogenesis, vol. 5, no. 2, pp. 73-82, 2009.

[10] C. M. Chen and G. Struhl, "Wingless transduction by the Frizzled and Frizzled2 proteins of Drosophila," Development, vol. 126, no. 23, pp. 5441-5452, 1999.

[11] P. Bhanot, M. Brink, C. H. Samos et al., "A new member of the frizzled family from Drosophila functions as a wingless receptor," Nature, vol. 382, no. 6588, pp. 225-231, 1996.

[12] P. Bhanot, M. Fish, J. A. Jemison, R. Nusse, J. Nathans, and K. M. Cadigan, "Frizzled and DFrizzled-9 function as redundant receptors for wingless during Drosophila embryonic development," Development, vol. 126, no. 18, pp. 4175-4186, 1999.

[13] C. E. Merkel, C. M. Karner, and T. J. Carroll, "Molecular regulation of kidney development: is the answer blowing in the Wnt?" Pediatric Nephrology, vol. 22, no. 11, pp. 1825$1838,2007$.

[14] L. Arce, N. N. Yokoyama, and M. L. Waterman, "Diversity of LEF/TCF action in development and disease," Oncogene, vol. 25, no. 57, pp. 7492-7504, 2006.

[15] M. Perez-Moreno and E. Fuchs, "Catenins: keeping cells from getting their signals crossed," Developmental Cell, vol. 11, no. 5, pp. 601-612, 2006.

[16] C. Karner, K. A. Wharton, and T. J. Carroll, "Planar cell polarity and vertebrate organogenesis," Seminars in Cell and Developmental Biology, vol. 17, no. 2, pp. 194-203, 2006.

[17] A. Kispert, S. Vainio, L. Shen, D. H. Rowitch, and A. P. McMahon, "Proteoglycans are required for maintenance of Wnt-11 expression in the ureter tips," Development, vol. 122, no. 11, pp. 3627-3637, 1996.

[18] T. J. Carroll, J. S. Park, S. Hayashi, A. Majumdar, and A. P. McMahon, "Wnt9b plays a central role in the regulation of mesenchymal to epithelial transitions underlying organogenesis of the mammalian urogenital system," Developmental Cell, vol. 9, no. 2, pp. 283-292, 2005.

[19] P. Itäranta, Y. Lin, J. Peräsaari, G. Roël, O. Destrée, and S. Vainio, "Wnt-6 is expressed in the ureter bud and induces kidney tubule development in vitro," Genesis, vol. 32, no. 4, pp. 259-268, 2002.

[20] Y. Lin, A. Liu, R. Zhang et al., "Induction of ureter branching as a response to Wnt-2b signaling during early kidney organogenesis," Developmental Dynamics, vol. 222, no. 1, pp. 26-39, 2001.

[21] K. Stark, S. Vainio, G. Vassileva, and A. P. McMahon, "Epithelial transformation metanephric mesenchyme in the developing kidney regulated by Wnt-4," Nature, vol. 372, no. 6507, pp. 679-683, 1996.

[22] T. D. Marose, C. E. Merkel, A. P. McMahon, and T. J. Carroll, " $\beta$-catenin is necessary to keep cells of ureteric bud/Wolffian duct epithelium in a precursor state," Developmental Biology, vol. 314, no. 1, pp. 112-126, 2008.

[23] D. Bridgewater, B. Cox, J. Cain et al., "Canonical WNT/ $\beta$ catenin signaling is required for ureteric branching," Developmental Biology, vol. 317, no. 1, pp. 83-94, 2008.

[24] E. Fischer, E. Legue, A. Doyen et al., "Defective planar cell polarity in polycystic kidney disease," Nature Genetics, vol. 38, no. 1, pp. 21-23, 2006.

[25] C. M. Karner, R. Chirumamilla, S. Aoki, P. Igarashi, J. B. Wallingford, and T. J. Carroll, "Wnt9b signaling regulates planar cell polarity and kidney tubule morphogenesis," Nature Genetics, vol. 41, no. 7, pp. 793-799, 2009.

[26] J. Yu, T. J. Carroll, J. Rajagopal, A. Kobayashi, Q. Ren, and A. P. McMahon, "A Wnt7b-dependent pathway regulates the orientation of epithelial cell division and establishes the cortico-medullary axis of the mammalian kidney," Development, vol. 136, no. 1, pp. 161-171, 2009.

[27] H. Kobori, Y. Ozawa, Y. Suzaki et al., "Young scholars award lecture: intratubular angiotensinogen in hypertension and kidney diseases," American Journal of Hypertension, vol. 19, no. 5, pp. 541-550, 2006.

[28] A. R. Brasier and J. Li, "Mechanisms for inducible control of angiotensinogen gene transcription," Hypertension, vol. 27, no. 3, pp. 465-475, 1996.

[29] L. G. Navar, "The kidney in blood pressure regulation and development of hypertension," Medical Clinics of North America, vol. 81, no. 5, pp. 1165-1178, 1997.

[30] M. Paul, A. P. Mehr, and R. Kreutz, "Physiology of local renin-angiotensin systems," Physiological Reviews, vol. 86, no. 3, pp. 747-803, 2006.

[31] M. Ito, M. I. Oliverio, P. J. Mannon et al., "Regulation of blood pressure by the type 1A angiotensin II receptor gene," Proceedings of the National Academy of Sciences of the United States of America, vol. 92, no. 8, pp. 3521-3525, 1995.

[32] H. M. Siragy and R. M. Carey, "The subtype-2 (AT) angiotensin receptor mediates renal production of nitric oxide in conscious rats," Journal of Clinical Investigation, vol. 100, no. 2, pp. 264-269, 1997.

[33] M. Goto, M. Mukoyama, S. I. Suga et al., "Growth-dependent induction of angiotensin II type 2 receptor in rat mesangial cells," Hypertension, vol. 30, no. 3, pp. 358-362, 1997.

[34] V. Gross, W. H. Schunck, H. Honeck et al., "Inhibition of pressure natriuresis in mice lacking the AT receptor," Kidney International, vol. 57, no. 1, pp. 191-202, 2000.

[35] M. Donoghue, F. Hsieh, E. Baronas et al., "A novel angiotensin-converting enzyme-related carboxypeptidase (ACE2) converts angiotensin I to angiotensin 1-9," Circulation Research, vol. 87, no. 5, pp. E1-E9, 2000.

[36] K. B. Brosnihan, P. Li, and C. M. Ferrario, "Angiotensin-(17) dilates canine coronary arteries through kinins and nitric oxide," Hypertension, vol. 27, no. 3, pp. 523-528, 1996.

[37] R. A. S. Santos, A. C. Simoes e Silva, C. Maric et al., "Angiotensin-(1-7) is an endogenous ligand for the G protein-coupled receptor Mas," Proceedings of the National Academy of Sciences of the United States of America, vol. 100, no. 14 , pp. 8258-8263, 2003. 
[38] R. A. Santos and A. J. Ferreira, "Angiotensin-(1-7) and the renin-angiotensin system," Current Opinion in Nephrology and Hypertension, vol. 16, no. 2, pp. 122-128, 2007.

[39] E. Hackenthal, M. Paul, D. Ganten, and R. Taugner, "Morphology, physiology, and molecular biology of renin secretion," Physiological Reviews, vol. 70, no. 4, pp. 10671116, 1990.

[40] H. Miyazaki, A. Fukamizu, and S. Hirose, "Structure of the human renin gene," Proceedings of the National Academy of Sciences of the United States of America, vol. 81, no. 19, pp. 5999-6003, 1984.

[41] F. Schweda, U. Friis, C. Wagner, O. Skott, and A. Kurtz, "Renin release," Physiology, vol. 22, no. 5, pp. 310-319, 2007.

[42] C. Cousin, D. Bracquart, A. Contrepas, P. Corvol, L. Muller, and G. Nguyen, "Soluble form of the (pro)renin receptor generated by intracellular cleavage by furin is secreted in plasma," Hypertension, vol. 53, no. 6, pp. 1077-1082, 2009.

[43] A. H. Jan Danser, F. H. M. Derkx, M. A. D. H. Schalekamp, H. W. Hense, G. A. J. Riegger, and H. Schunkert, "Determinants of interindividual variation of renin and prorenin concentrations: evidence for a sexual dimorphism of (pro)renin levels in humans," Journal of Hypertension, vol. 16, no. 6, pp. 853862, 1998.

[44] G. Nguyen, F. Delarue, C. Burcklé, L. Bouzhir, T. Giller, and J. D. Sraer, "Pivotal role of the renin/prorenin receptor in angiotensin II production and cellular responses to renin," Journal of Clinical Investigation, vol. 109, no. 11, pp. 14171427, 2002.

[45] G. Nguyen and D. N. Muller, "The biology of the (pro)renin receptor," Journal of the American Society of Nephrology, vol. 21, no. 1, pp. 18-23, 2010.

[46] C. A. Jones, C. D. Sigmund, R. A. McGowan, C. M. KaneHaas, and K. W. Gross, "Expression of murine renin genes during fetal development," Molecular Endocrinology, vol. 4, no. 3, pp. 375-383, 1990.

[47] R. A. Gomez, K. R. Lynch, B. C. Sturgill et al., "Distribution of renin mRNA and its protein in the developing kidney," American Journal of Physiology, vol. 257, no. 5, pp. F850F858, 1989.

[48] S. Schütz, J. M. Le Moullec, P. Corvol, and J. M. Gasc, "Early expression of all the components of the renin-angiotensinsystem in human development," American Journal of Pathology, vol. 149, no. 6, pp. 2067-2079, 1996.

[49] M. L. S. Sequeira Lopez, E. S. Pentz, B. Robert, D. R. Abrahamson, and R. A. Gomez, "Embryonic origin and lineage of juxtaglomerular cells," American Journal of Physiology, vol. 281, no. 2, pp. F345-F356, 2001.

[50] I. V. Yosipiv and S. S. El-Dahr, "Activation of angiotensingenerating systems in the developing rat kidney," Hypertension, vol. 27, no. 2, pp. 281-286, 1996.

[51] Y. Miyazaki, S. Tsuchida, H. Nishimura et al., "Angiotensin induces the urinary peristaltic machinery during the perinatal period," Journal of Clinical Investigation, vol. 102, no. 8, pp. 1489-1497, 1998.

[52] A. Advani, D. J. Kelly, A. J. Cox et al., "The (Pro)renin receptor: site-specific and functional linkage to the vacuolar $\mathrm{H}+$-atpase in the kidney," Hypertension, vol. 54, no. 2, pp. 261-269, 2009.

[53] M. Sakoda, A. Ichihara, A. Kurauchi-Mito et al., "Aliskiren inhibits intracellular angiotensin ii levels without affecting (Pro)renin Receptor Signals in Human Podocytes," American Journal of Hypertension, vol. 23, no. 5, pp. 575-580, 2010.

[54] T. Hirose, N. Mori, K. Totsune et al., "Gene expression of (pro)renin receptor is upregulated in hearts and kidneys of rats with congestive heart failure," Peptides, vol. 30, no. 12, pp. 2316-2322, 2009.

[55] W. W. Batenburg, M. Krop, I. M. Garrelds et al., "Prorenin is the endogenous agonist of the (pro)renin receptor. Binding kinetics of renin and prorenin in rat vascular smooth muscle cells overexpressing the human (pro)renin receptor," Journal of Hypertension, vol. 25, no. 12, pp. 2441-2453, 2007.

[56] C. M. Cruciat, B. Ohkawara, S. P. Acebron et al., "Requirement of prorenin receptor and vacuolar H-ATPase-mediated acidification for Wnt signaling," Science, vol. 327, no. 5964, pp. 459-463, 2010.

[57] K. H. Yoo, J. T. Wolstenholme, and R. L. Chevalier, "Angiotensin-converting enzyme inhibition decreases growth factor expression in the neonatal rat kidney," Pediatric Research, vol. 42, no. 5, pp. 588-592, 1997.

[58] A. Tufro-McRreddie, L. M. Romano, J. M. Harris, L. Ferder, and R. A. Gomez, "Angiotensin II regulates nephrogenesis and renal vascular development," American Journal of Physiology, vol. 269, no. 1, pp. F110-F115, 1995.

[59] C. Schaefer, "Angiotensin II-receptor-antagonists: further evidence of fetotoxicity but not teratogenicity," Birth Defects Research A, vol. 67, no. 8, pp. 591-594, 2003.

[60] S. Tabacova, R. Little, Y. Tsong, A. Vega, and C. A. Kimmel, "Adverse pregnancy outcomes associated with maternal enalapril antihypertensive treatment," Pharmacoepidemiology and Drug Safety, vol. 12, no. 8, pp. 633-646, 2003.

[61] M. Nagata, K. Tanimoto, A. Fukamizu et al., "Nephrogenesis and renovascular development in angiotensinogen-deficient mice," Laboratory Investigation, vol. 75, no. 5, pp. 745-753, 1996.

[62] F. Niimura, P. A. Labosky, J. Kakuchi et al., "Gene targeting in mice reveals a requirement for angiotensin in the development and maintenance of kidney morphology and growth factor regulation," Journal of Clinical Investigation, vol. 96, no. 6, pp. 2947-2954, 1995.

[63] N. Takahashi, M. L. S. S. Lopez, J. E. Cowhig et al., "Ren1c homozygous null mice are hypotensive and polyuric, but heterozygotes are indistinguishable from wild-type," Journal of the American Society of Nephrology, vol. 16, no. 1, pp. 125132, 2005.

[64] C. R. Esther Jr., T. E. Howard, E. M. Marino, J. M. Goddard, M. R. Capecchi, and K. E. Bernstein, "Mice lacking angiotensin-converting enzyme have low blood pressure, renal pathology, and reduced male fertility," Laboratory Investigation, vol. 74, no. 5, pp. 953-965, 1996.

[65] M. I. Oliverio, H. S. Kim, M. Ito et al., "Reduced growth, abnormal kidney structure, and type $2\left(\mathrm{AT}_{2}\right)$ angiotensin receptor-mediated blood pressure regulation in mice lacking both $\mathrm{AT}_{1 A}$ and $\mathrm{AT}_{1 B}$ receptors for angiotensin II," Proceedings of the National Academy of Sciences of the United States of America, vol. 95, no. 26, pp. 15496-15501, 1998.

[66] S. Tsuchida, T. Matsusaka, X. Chen et al., "Murine double nullizygotes of the angiotensin type $1 \mathrm{~A}$ and $1 \mathrm{~B}$ receptor genes duplicate severe abnormal phenotypes of angiotensinogen nullizygotes," Journal of Clinical Investigation, vol. 101, no. 4, pp. 755-760, 1998.

[67] M. Srougi, L. J. Nesrallah, J. R. Kauffmann, A. Nesralleh, K. R. M. Leite, and M. S. Soloway, "Angiotensin type II receptor expression and ureteral budding," Journal of Urology, vol. 166, no. 5, pp. 1848-1852, 2001.

[68] O. Gribouval, M. Gonzales, T. Neuhaus et al., "Mutations in genes in the renin-angiotensin system are associated with autosomal recessive renal tubular dysgenesis," Nature Genetics, vol. 37, no. 9, pp. 964-968, 2005. 
[69] M. Lacoste, Y. Cai, L. Guicharnaud et al., "Renal tubular dysgenesis, a not uncommon autosomal recessive disorder leading to oligohydramnios: role of the renin-angiotensin system," Journal of the American Society of Nephrology, vol. 17, no. 8, pp. 2253-2263, 2006.

[70] G. Sihn, A. Rousselle, L. Vilianovitch, C. Burckle, and M. Bader, "Physiology of the (pro)renin receptor: wnt of change?” Kidney International, vol. 78, no. 3, pp. 246-256, 2010.

[71] K. Kinouchi, A. Ichihara, M. Sano et al., "The (pro)renin receptor/atp6ap2 is essential for vacuolar $\mathrm{H}+$-ATPase assembly in murine cardiomyocytes," Circulation Research, vol. 107, no. 1, pp. 30-34, 2010.

[72] Y. Huang, S. Wongamorntham, J. Kasting et al., "Renin increases mesangial cell transforming growth factor- $\beta 1$ and matrix proteins through receptor-mediated, angiotensin IIindependent mechanisms," Kidney International, vol. 69, no. 1, pp. 105-113, 2006.

[73] J. H. Schefe, M. Menk, J. Reinemund et al., "A novel signal transduction cascade involving direct physical interaction of the renin/prorenin receptor with the transcription factor promyelocytic zinc finger protein," Circulation Research, vol. 99, no. 12, pp. 1355-1366, 2006.

[74] S. Feldt, W. W. Batenburg, I. Mazak et al., "Prorenin and renin-induced extracellular signal-regulated kinase $1 / 2$ activation in monocytes is not blocked by aliskiren or the handle-region peptide," Hypertension, vol. 51, no. 3, pp. 682$688,2008$.

[75] G. Liu, H. Hitomi, N. Hosomi et al., "Prorenin induces vascular smooth muscle cell proliferation and hypertrophy via epidermal growth factor receptor-mediated extracellular signal-regulated kinase and Akt activation pathway," Journal of Hypertension, vol. 29, no. 4, pp. 696-705, 2011.

[76] J. Ramser, F. E. Abidi, C. A. Burckle et al., "A unique exonic splice enhancer mutation in a family with X-linked mental retardation and epilepsy points to a novel role of the renin receptor," Human Molecular Genetics, vol. 14, no. 8, pp. 1019 1027, 2005.

[77] C. A. Burcklé, A. H. J. Danser, D. N. Müller et al., "Elevated blood pressure and heart rate in human renin receptor transgenic rats," Hypertension, vol. 47, no. 3, pp. 552-556, 2006.

[78] A. Ichihara, Y. Kaneshiro, T. Takemitsu et al., "Nonproteolytic activation of prorenin contributes to development of cardiac fibrosis in genetic hypertension," Hypertension, vol. 47, no. 5, pp. 894-900, 2006.

[79] T. Buechling, K. Bartscherer, B. Ohkawara et al., "Wnt/Frizzled signaling requires dPRR, the Drosophila homolog of the prorenin receptor," Current Biology, vol. 20, no. 14, pp. 1263-1268, 2010.

[80] T. Hirose, M. Hashimoto, K. Totsune et al., "Association of (pro)renin receptor gene polymorphism with blood pressure in Japanese men: the Ohasama study," American Journal of Hypertension, vol. 22, no. 3, pp. 294-299, 2009.

[81] T. Hirose, M. Hashimoto, K. Totsune et al., "Association of (pro)renin receptor gene polymorphisms with lacunar infarction and left ventricular hypertrophy in Japanese women: the Ohasama study," Hypertension Research, vol. 34, no. 4, pp. 530-535, 2011.

[82] R. Song and I. V. Yosypiv, "Genetics of congenital anomalies of the kidney and urinary tract," Pediatric Nephrology, vol. 26, no. 3, pp. 353-364, 2011.

[83] I. Spinello, M. T. Quaranta, L. Pasquini et al., "PLZFmediated control on c-kit expression in CD34 $(+)$ cells and early erythropoiesis," Oncogene, vol. 28, no. 23, pp. 22762288, 2009.

[84] K. M. Schmidt-Ott, T. N. H. Masckauchan, X. Chen et al., " $\beta$-catenin/TCF/Lef controls a differentiation-associated transcriptional program in renal epithelial progenitors," Development, vol. 134, no. 17, pp. 3177-3190, 2007.

[85] M. J. Tang, Y. Cai, SI. J. Tsai, Y. K. Wang, and G. R. Dressler, "Ureteric bud outgrowth in response to RET activation is mediated by phosphatidylinositol 3-kinase," Developmental Biology, vol. 243, no. 1, pp. 128-136, 2002.

[86] R. Song, M. Spera, C. Garrett, and I. V. Yosypiv, "Angiotensin II-induced activation of c-Ret signaling is critical in ureteric bud branching morphogenesis," Mechanisms of Development, vol. 127, no. 1-2, pp. 21-27, 2010.

[87] I. V. Yosypiv, M. Schroeder, and S. S. El-Dahr, "AT1R-EGFR crosstalk regulates ureteric bud branching morphogenesis," Journal of the American Society of Nephrology, vol. 17, no. 4, pp. 1005-1014, 2006.

[88] Y. Yan, N. Denef, and T. Schüpbach, "The vacuolar proton pump, V-ATPase, is required for notch signaling and endosomal trafficking in Drosophila," Developmental Cell, vol. 17, no. 3, pp. 387-402, 2009.

[89] H. T. Cheng, M. Kim, M. T. Valerius et al., "Notch2, but not Notch1, is required for proximal fate acquisition in the mammalian nephron," Development, vol. 134, no. 4, pp. 801811, 2007.

[90] H. W. Jeong, S. J. Un, B. K. Koo et al., "Inactivation of Notch signaling in the renal collecting duct causes nephrogenic diabetes insipidus in mice," Journal of Clinical Investigation, vol. 119, no. 11, pp. 3290-3300, 2009.

[91] Y. Kaneshiro, A. Ichihara, M. Sakoda et al., "Slowly progressive, angiotensin II-independent glomerulosclerosis in human (pro)renin receptor-transgenic rats," Journal of the American Society of Nephrology, vol. 18, no. 6, pp. 1789-1795, 2007.

[92] B. Peters, O. Grisk, B. Becher et al., "Dose-dependent titration of prorenin and blood pressure in Cyplalren-2 transgenic rats: absence of prorenin-induced glomerulosclerosis," Journal of Hypertension, vol. 26, no. 1, pp. 102-109, 2008.

[93] C. Mercure, G. Prescott, M. J. Lacombe, D. W. Silversides, and T. L. Reudelhuber, "Chronic increases in circulating prorenin are not associated with renal or cardiac pathologies," Hypertension, vol. 53, no. 6, pp. 1062-1069, 2009.

[94] G. Prescott, D. W. Silversides, and T. L. Reudelhuber, "Tissue activity of circulating prorenin," American Journal of Hypertension, vol. 15, no. 3, pp. 280-285, 2002.

[95] A. Ichihara, Y. Kaneshiro, T. Takemitsu et al., "Contribution of nonproteolytically activated prorenin in glomeruli to hypertensive renal damage," Journal of the American Society of Nephrology, vol. 17, no. 9, pp. 2495-2503, 2006.

[96] R. P. Lifton, "Genetic determinants of human hypertension," Proceedings of the National Academy of Sciences of the United States of America, vol. 92, no. 19, pp. 8545-8551, 1995.

[97] C. Newton-Cheh, T. Johnson, V. Gateva et al., "Genome-wide association study identifies eight loci associated with blood pressure," Nature Genetics, vol. 41, no. 6, pp. 666-676, 2009.

[98] X. Zhu, Y. P. C. Chang, D. Yan et al., "Associations between hypertension and genes in the renin-angiotensin system," Hypertension, vol. 41, no. 5, pp. 1027-1034, 2003.

[99] S. Schmidt, I. M. S. Van Hooft, D. E. Grobbee, D. Ganten, and E. Ritz, "Polymorphism of the angiotensin I converting enzyme gene is apparently not related to high blood pressure: 
Dutch hypertension and offspring study," Journal of Hypertension, vol. 11, no. 4, pp. 345-348, 1993.

[100] F. Hildebrandt, "Genetic kidney diseases," The Lancet, vol. 375, no. 9722, pp. 1287-1295, 2010.

[101] M. Barna, N. Hawe, N. Lee, and P. P. Pandolf, "Plzf regulates limb and axial skeletal patterning," Nature Genetics, vol. 25, no. 2, pp. 166-172, 2000.

[102] G. R. Dressler, "Advances in early kidney specification, development and patterning," Development, vol. 136, no. 23, pp. 3863-3874, 2009.

[103] F. Grignani, S. De Matteis, C. Nervi et al., "Fusion proteins of the retinoic acid receptor- $\alpha$ recruit histone deacetylase in promyelocytic leukaemia," Nature, vol. 391, no. 6669, pp. 815-818, 1998.

[104] G. Lagger, D. O'Carroll, M. Rembold et al., "Essential function of histone deacetylase 1 in proliferation control and CDK inhibitor repression," EMBO Journal, vol. 21, no. 11, pp. 2672-2681, 2002.

[105] C. Rosselot, L. Spraggon, I. Chia et al., "Non-cellautonomous retinoid signaling is crucial for renal development," Development, vol. 137, no. 2, pp. 283-292, 2010.

[106] E. S. Pentz, M. L. S. Sequeira Lopez, M. Cordaillat, and R. A. Gomez, "Identity of the renin cell is mediated by cAMP and chromatin remodeling: an in vitro model for studying cell recruitment and plasticity," American Journal of Physiology, vol. 294, no. 2, pp. H699-H707, 2008.

[107] R. Song, T. Van Buren, and I. V. Yosypiv, "Histone deacetylases are critical regulators of the renin-angiotensin system during ureteric bud branching morphogenesis," Pediatric Research, vol. 67, no. 6, pp. 573-578, 2010.

[108] D. Filipponi, R. M. Hobbs, S. Ottolenghi et al., "Repression of kit expression by Plzf in germ cells," Molecular and Cellular Biology, vol. 27, no. 19, pp. 6770-6781, 2007.

[109] Y. Li, B. Pawlik, N. Elcioglu et al., "LRP4 mutations alter Wnt/beta-catenin signaling and cause limb and kidney malformations in Cenani-Lenz syndrome," American Journal of Human Genetics, vol. 86, no. 5, pp. 696-706, 2010.

[110] M. Toei, R. Saum, and M. Forgac, "Regulation and isoform function of the V-ATPases," Bochemistry, vol. 49, no. 23, pp. 4715-4723, 2010.

[111] F. E. Karet, K. E. Finberg, R. D. Nelson et al., "Mutations in the gene encoding B1 subunit of $\mathrm{H}+$-ATPase cause renal tubular acidosis with sensorineural deafness," Nature Genetics, vol. 21, no. 1, pp. 84-90, 1999.

[112] A. N. Smith, J. Skaug, K. A. Choate et al., "Mutations in ATP6N1B, encoding a new kidney vacuolar proton pump $116-\mathrm{kD}$ subunit, cause recessive distal renal tubular acidosis with preserved hearing," Nature Genetics, vol. 26, no. 1, pp. 71-75, 2000.

[113] H. Inoue, T. Noumi, M. Nagata, H. Murakami, and H. Kanazawa, "Targeted disruption of the gene encoding the proteolipid subunit of mouse vacuolar H-ATPase leads to early embryonic lethality," Biochimica et Biophysica Acta, vol. 1413, no. 3, pp. 130-138, 1999.

[114] G. I. Miura, G. J. Froelick, D. J. Marsh, K. L. Stark, and R. D. Palmiter, "The d subunit of the vacuolar ATPase (Atp6d) is essential for embryonic development," Transgenic Research, vol. 12, no. 1, pp. 131-133, 2003.

[115] Y. P. Li, W. Chen, Y. Liang, E. Li, and P. Stashenko, "Atp6i-deficient mice exhibit severe osteopetrosis due to loss of osteoclast-mediated extracellular acidification," Nature Genetics, vol. 23, no. 4, pp. 447-451, 1999.

[116] K. E. Finberg, G. A. Wagner, M. A. Bailey et al., "The B1subunit of the H ATPase is required for maximal urinary acidification," Proceedings of the National Academy of Sciences of the United States of America, vol. 102, no. 38, pp. 13616$13621,2005$.

[117] R. McDaniell, D. M. Warthen, P. A. Sanchez-Lara et al., "NOTCH2 mutations cause Alagille syndrome, a heterogeneous disorder of the notch signaling pathway," American Journal of Human Genetics, vol. 79, no. 1, pp. 169-173, 2006.

[118] M. C. Prieto-Carrasquero, F. T. Botros, H. Kobori, and L. G. Navar, "Collecting duct renin: a major player in angiotensin II-dependent hypertension," Journal of the American Society of Hypertension, vol. 3, no. 2, pp. 96-104, 2009.

[119] M. Simons, W. J. Gault, D. Gotthardt et al., "Electrochemical cues regulate assembly of the Frizzled/Dishevelled complex at the plasma membrane during planar epithelial polarization," Nature Cell Biology, vol. 11, no. 3, pp. 286-294, 2009.

[120] C. E. Fisher, L. Michael, M. W. Barnett, and J. A. Davies, "Erk MAP kinase regulates branching morphogenesis in the developing mouse kidney," Development, vol. 128, no. 21, pp. 4329-4338, 2001.

[121] M. P. Sánchez, I. Silos-Santiago, J. Frisen, B. He, S. A. Lira, and M. Barbacid, "Renal agenesis and the absence of enteric neurons in mice lacking GDNF," Nature, vol. 382, no. 6586, pp. 70-73, 1996.

[122] A. Schuchardt, V. D’Agati, V. Pachnis, and F. Costantin, "Renal agenesis and hypodysplasia in ret-k mutant mice result from defects in ureteric bud development," Development, vol. 122, no. 6, pp. 1919-1929, 1996. 


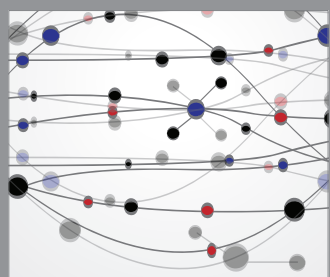

The Scientific World Journal
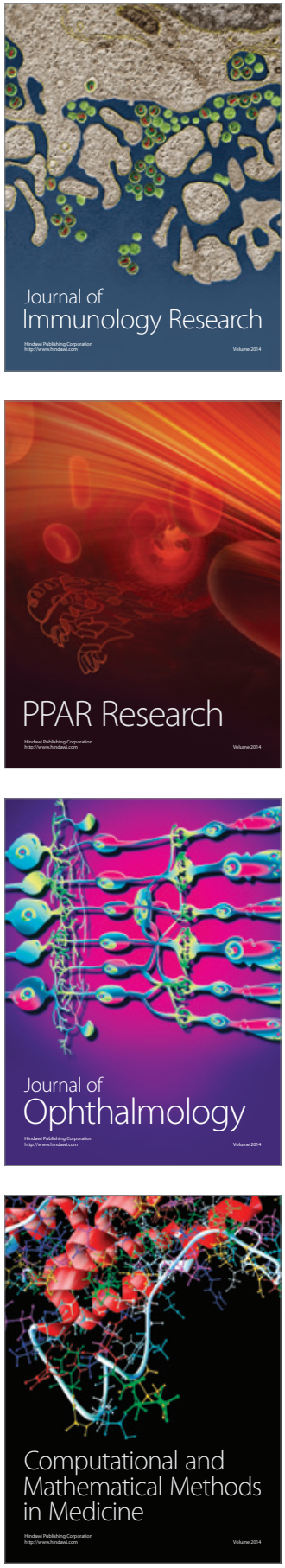

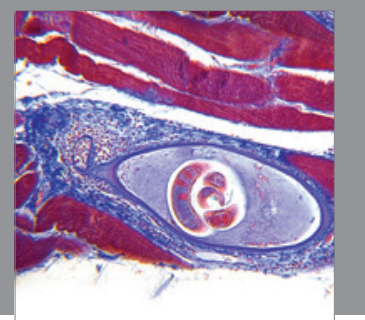

Gastroenterology

Research and Practice
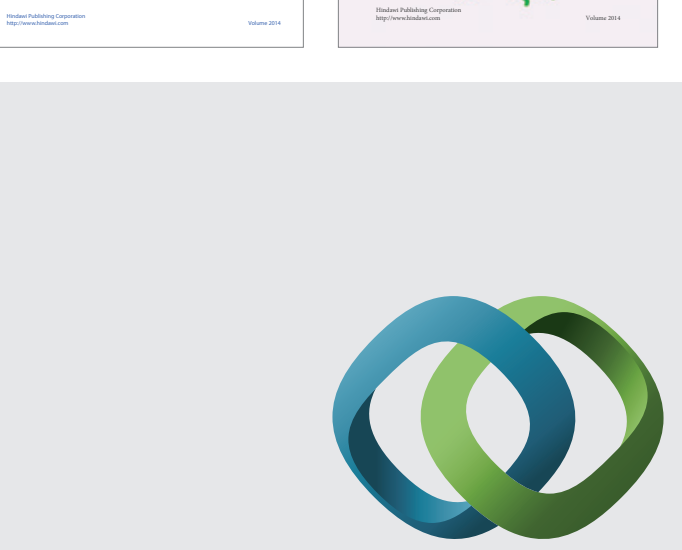

\section{Hindawi}

Submit your manuscripts at

http://www.hindawi.com
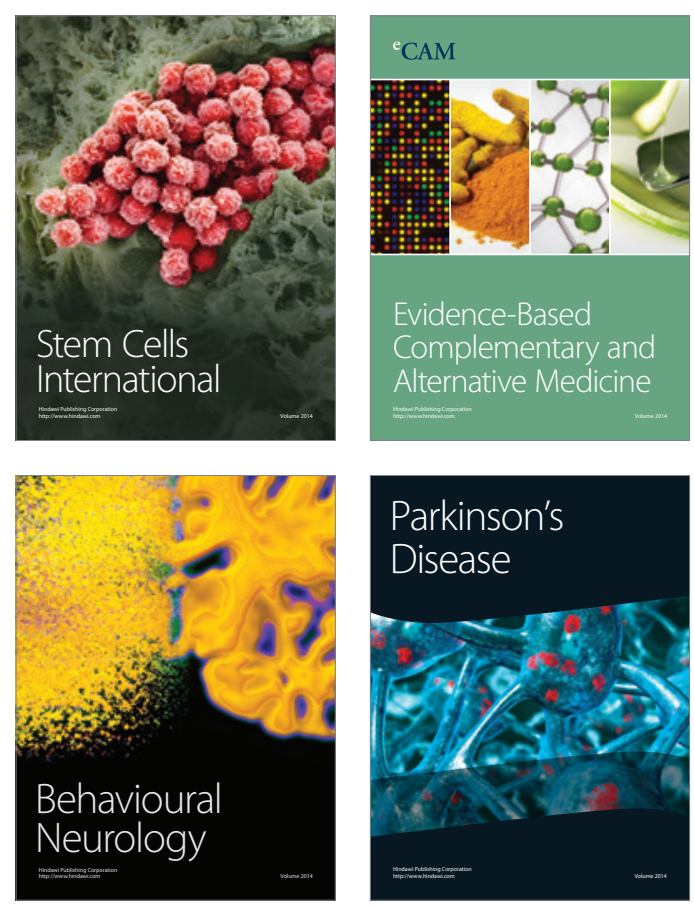

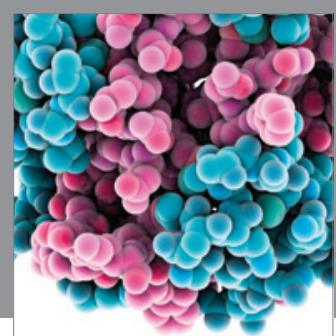

Journal of
Diabetes Research

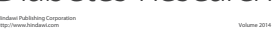

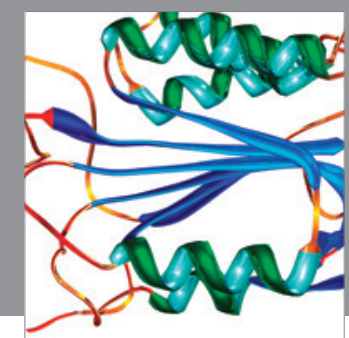

Disease Markers
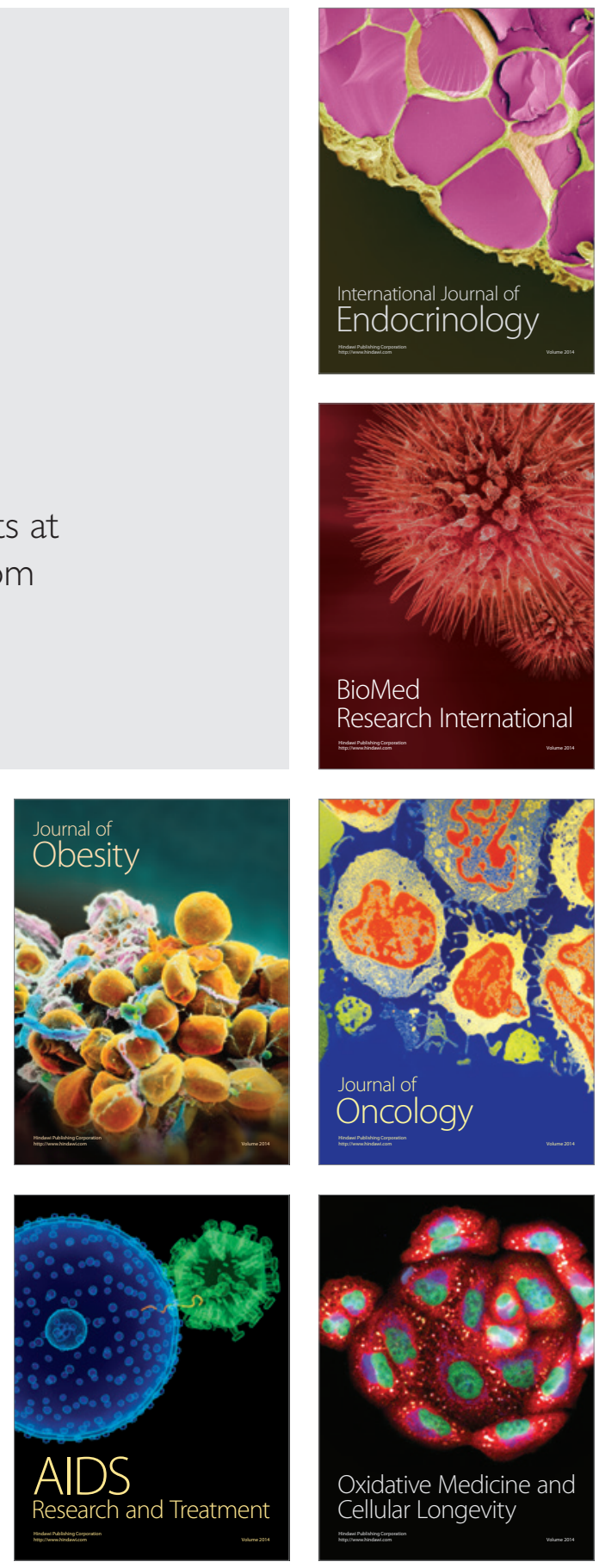